Proceedings of the Creative Construction Conference (2018)

Edited by: Miroslaw J. Skibniewski \& Miklos Hajdu

DOI 10.3311/CCC2018-050

Creative Construction Conference 2018, CCC 2018, 30 June - 3 July 2018, Ljubljana, Slovenia

\title{
Construction Productivity and Construction Project Performance in Indian Construction Projects
}

\author{
Saurav Dixit ${ }^{\text {a*, Satya N Mandal }}{ }^{\mathrm{a}}$, Joseph V Thanikal, Kinshuk Saurabh ${ }^{\mathrm{b}}$, \\ ${ }^{a}$ RICS School of Built Environment, Amity University, $5^{\text {th }}$ floor, F2 Block, Noida-201313, India \\ ${ }^{b}$ Indian School of Business (ISB), Mohali, India
}

\begin{abstract}
In order to ensure the performance of a project, it should be defined in terms of some measurable key parameters. Past researchers have identified project performance parameters such as cost, safety, construction productivity, and quality. Amongst all of them, construction productivity is one of the most reliable parameters of project performance. Performance can be measured at various levels including sector, organization, activity and project level in projectbased organizations. The methodology adopted to conduct the study is to collect the data through a structured questionnaire survey using convenient sampling technique. The number of variables selected from the literature for the study is 26 and the targeted data collection for the study is 125.The collected data has been analyzed using relative importance index (RII) to priorities the variables on the basis of their relative importance. The findings of the study concludes that the most significant 3 attributes impacting CPP are projected coordination meetings, coordination between all stakeholders, and top management support to PM having a relative value of 0.84, 0.82, and 0.69 respectively. SPSS 21 software tool has been used to check the reliability of the data and to perform factor analysis and the factors are pre-construction management, financial management, socio-economic management, coordination and communication management, resource management, commercial management, site management, and rework explains a variance of $14 \%, 10.3 \%, 9.1 \%, 7.1 \%, 6.3 \%, 6 \%, 5 \%$, and $4.3 \%$ respectively.
\end{abstract}

(C) 2018 The Authors. Published by Diamond Congress Ltd., Budapest University of Technology and Economics Peer-review under responsibility of the scientific committee of the Creative Construction Conference 2018.

Keywords: Construction Productivity; Construction Project Performance; Indian Construction Projects; Factors; and Project Management.

\section{Introduction}

The construction industry is having a significant importance in the economic, social, and infrastructure development of any country. It provides employment to the masses, promotes growth, and acts as a linkage to all the other sectors and the economy[1] [2]. Therefore the growth in the construction sector has a significant impact on the economy of the nation. Gains from higher construction productivity flow through the economy, as all industries rely on construction to some extent as part of their business investment. The construction sector is the engine of growth for any country and contributes about 8-10\% to the GDP on an average[3]. Provides employment to masses and create a flow of services and goods with other sectors. The measures to be done to improve the performance of construction projects has been identified critical and troublesome problems [4]. [5].The construction industry faced a number of issues and the downward trend of productivity has been studied by a number of researchers for many years [6]. "In general terms, construction productivity can be simply illustrated by an association between an output and an input i.e. Productivity= Output/Input". Productivity is commonly defined as a ratio of a volume measure of output to a volume measure of input use (OECD Manual)[8].

Corresponding author: Saurav Dixit: sdixit@ ricssbe.edu.in 
Performance can be measured at various levels including sector, organisation, activity and project level in projectbased organizations. At the sector level, productivity is one of the important measures of performance of projects. Productivity has been defined as "a ratio of a volume measure of output to a volume measure of input use" (OECD, 2001, p.11). This meaning of productivity depends on available costs of output and sources of input utilized. The Construction sector experiencing a downward trend in the productivity growth and a number of a researcher working to identify and analyse the issue, and factors affecting productivity [9][10] [11][12]. The productivity of projects is measured by rewarding, controlling and monitoring the performance, and to do the benchmarking to set the firm's future strategy that to be aligned to the basic objective of enhancing profit. Project performance metrics are used for post evaluation of the completed projects. Project performance matrix designed to measure and compare planned and actual performance of a specific project. Performance of a construction project could be influenced by a number of attributes, especially large and complex projects lay additional focus on the success/ failure attributes, because of the intensive amount of money invested, a high degree of uncertainty, the complexity of personnel required, a multiplicity of goals and problems in coordination between different stakeholders encountered. In this research paper, the author intended to define and examine the relationship between construction productivity $(\mathrm{CP})$ and construction project performance (CPP). The author tests the proposition that there is a positive relationship between both of them.

Table 1 the issues and challenges in construction productivity

\begin{tabular}{ll}
\hline Impacts & References \\
\hline Construction industry experienced a downward trend in the productivity growth & {$[9][13][10][11]$} \\
$\begin{array}{l}\text { The study pertaining to causes of time, cost overruns and low productivity in construction projects have been } \\
\text { conducted worldwide }\end{array}$ & {$[22][23][15][16][17][18][19]$} \\
$\begin{array}{l}\text { The productivity of UK's construction sector is declining and it is lower than as compared to few European } \\
\text { countries }\end{array}$ & {$[17][22]$} \\
Construction productivity has been affected by a number of factors, which tend to losses of revenues, delay & {$[7]$} \\
in completion, poor quality and other issues in construction projects & {$[19][25]$} \\
The decline in productivity is one of the dangers to the economy, because it creates social conflict, and & {$[24][6]$} \\
creates inflationary pressure & {$[6],[11],[25]$} \\
The authors concluded that the growth in construction productivity is negative & {$[26],[27]$} \\
The author's observed that the industry shifting is also the reason for low productivity & {$[8],[28],[29]$} \\
CP is one of the main drivers for completing projects within time and cost limitations & \\
Appropriate estimation of CP is quite important for preparing construction schedules and budgets &
\end{tabular}

1.1 Objectives of the research paper are:

I. To identify the attributes affecting construction productivity through literature review.

II. Impact of the construction productivity attributes over the performance of the projects.

\section{Literature review}

The success of any project is repeatable and it is possible to find out a set of certain success attributes for the success of a construction project and it requires a controlled discipline hardworking [3].The productivity of construction projects is one of the measures for performance of the construction projects at the industry level based on its relationship with economic development. And most countries encounter the issue of low productivity as per the statistical data available[30]-[32]. Whereas growth in construction productivity is low and do not continue progressive for a long span of time. In construction projects, the partial measure of productivity is the measure of labour productivity, machine productivity and consumption of materials [35]. These investigations run from hypothetical work in view of understanding of scientist toward one side to organized research deal with the other end. The tools used by the past researchers are AHP (analytical hierarchy process), structures to collect data, simulation models to predict the productivity, framework to improve productivity, techniques to measure productivity, and neural networks systems.

Performance of a project can be considered as a result of the processes as well as the presence of processes [19], [33]. [3], [34]stated that construction time is important because it often serves as a benchmark for assessing the performance categories such as people, cost, time, quality, safety and health. It is studied by [35] that human factors played an important role in determining the performance of a project. Completing projects in a predictable manner of time (within schedule) is one of the important indicators of project success. Cost overrun is one of the most frequent 
problems with construction projects and contractors are criticized for the common occurrence of cost overrun in construction projects, [36], [37]. There are some other factors which also contribute to the cost overrun such as profit of the project, project design cost, and wastage of materials, construction productivity, cost of variation orders and cost of rework. [37]this study sets out to assess the effect of construction productivity on the project performance of Indian construction industry, using a survey design with construction professionals sampled, the study has been able to ascertain the factors affecting the construction productivity of construction projects in India, and the areas in project performance that is affected by construction productivity.

Table 2 summary of attributes/variables identified by previous researchers in the field of construction productivity

\begin{tabular}{|c|c|}
\hline Attributes/variables & References \\
\hline Increases in land-use regulation & [38] \\
\hline Equipment, drawing, tools, availability of material, weather condition & [39], [40],[41], [42] \\
\hline Labour management, rework, material, confined working space, tools & [34], [43] \\
\hline Delays in inspection, decision taking, material, rework, tools and equipment & [43]-[45] \\
\hline Absenteeism, Rework and lack of material & [46], [47] \\
\hline Shop drawings, equipment's, motivation and support, scheduling, material & {$[48]$} \\
\hline Revision in drawings, delays in inspection, competency of supervisor, martial availability & [43] \\
\hline Project management, planning and scheduling, top management support, rework & {$[49],[50],[21]$} \\
\hline $\begin{array}{l}\text { Coordination among all team members, leadership, top management support, the flow of funds, budget } \\
\text { update, coordination and communication, timely feedback, and owner's competence and favourable } \\
\text { climatic condition. }\end{array}$ & {$[3][51],[52]$} \\
\hline Rework, Poor supervisor competency and Incomplete drawings & {$[43],[53],[54]$} \\
\hline $\begin{array}{l}\text { Decision making, planning \& logistics, supply chain management, labour availability, budget \& cash flow } \\
\text { management, improper construction method, frequent changes in design, supervision delay, the sequence } \\
\text { of activities, overcrowding a job location and scope of activities. }\end{array}$ & {$[51],[55][26][56][52]$} \\
\hline $\begin{array}{l}\text { Availability of material, the experience of labour, skill set and training, communication, the financial } \\
\text { position of the client }\end{array}$ & [57][26], [40] \\
\hline
\end{tabular}

\section{Research Methodology}

3.1 Questionnaire survey

To investigate the impact of construction productivity on the performance of construction project a structured questionnaire survey method was adopted. This research paper follows a specific structured methodology. First, the literature review is conducted of all the research work related to the construction productivity and project performance, which is followed by identification of variables/attributes affecting construction productivity (table I). Thereafter a consolidated list has been prepared for the attributes identified through literature review and in addition few other variables were also included in the list identified through industry expert opinion. On the basis of these attributes, a structured questionnaire was prepared which consists of three main parts such as:

I. Introduction to the research and the basic information needed from the respondents.

II. The questionnaire itself.

III. Last part of the questionnaire is provided for suggestions from the respondents.

The respondents were asked to rank the attributes on five points Likert scale on the basis of their impact on the project performance. The points on the Likert scale $(1=$ adversely affecting the performance, $2=$ significantly affecting the performance, $3=$ no effect on performance, $4=$ marginally help in improving performance and $5=$ significantly help in improving performance)

\subsection{Sampling and data collection}

The questionnaire is shared with 350 professionals working in different firms and organisations all over the Indian construction industry. The respondents were chosen randomly to make the study unbiased. A total of 125 valid responses were received with a response rate of $35.7 \%$. The received responses were analysed using factor analysis to reduce dimensions of the attributes because it is not easy to understand the impact of 26 attributes on the project performance. The primary component analysis is used for dimension reduction. 


\subsection{Relative importance index (RII)}

Relative importance index is used to calculate the weighted average of the different attributes selected for the study [5], [58]-[60]. RII is calculated using the formula mentioned equation (1). Where ' $r$ ' represent the rating provided on the Likert scale, ' $\mathrm{n}$ ' is the respondents proving the same rating, and ' $\mathrm{N}$ ' is the total number of valid responses received. A number of researchers applied RII to analyse the attributes and to rank them on the weighted average value calculated[3], [19], [43], [58], [61]-[64].

$$
\text { Rii }=\frac{\sum_{\mathrm{r}=1}^{5} \mathrm{r}^{*} \mathrm{n}_{\mathrm{r}}}{\text { 3.3.1 Most significant factors affecting CPP }}
$$

The most significant factors affecting CPP are project coordination meetings, coordination between all stakeholders, and top management support to PM having a relative importance of $0.84,0.82$, and 0.69 respectively. The study reveals that coordination and interaction between the team and between the stakeholders plays a significant role in the CPP[57],[67].

Table 3 relative importance index (RII)

\begin{tabular}{llll}
\hline $\begin{array}{c}\text { Total } \\
\text { score }\end{array}$ & RII & Attribute name & Rank \\
\hline 524 & 0.84 & Project coordination meetings & 1 \\
512 & 0.82 & Coordination between all stakeholders & 2 \\
508 & 0.69 & top management support to pm & 3 \\
484 & 0.69 & Scope clarity of the project & 4 \\
477 & 0.69 & timely payment of completed works & 5 \\
477 & 0.68 & availability of resources & 6 \\
476 & 0.68 & Availability of training and development for enhancing skills & 7 \\
465 & 0.67 & regular budget update & 8 \\
461 & 0.67 & developing and maintaining communication & 9 \\
453 & 0.67 & PM authority to make financial decisions & 10 \\
\hline
\end{tabular}

\subsection{Reliability analysis}

The value of reliability is lain between 0 to 1 , the more near to 1 is more the reliable results[3].Reliability analysis provides us with the confidence level that the data collected for the study is reliable and shall be used to generalise the findings of the study. The overall value of reliability for all the attributes is 0.703 which is considered as good to validate the findings[66].

Table 4 reliability analysis

\begin{tabular}{ll}
\hline Variables & Cronbach's alpha $(\mathrm{C} \alpha)$ \\
\hline Overall variables selected for the study & 0.703 \\
\hline
\end{tabular}

\subsection{Factor analysis}

Factor analysis enables us to reduce the number of dimensions of the data and to draw a table on the basis of variance explained by the constructs/factors, and factor loading of the different attributes in factors. For the current study, the attributes having a factor loading of equal and more than of 0.4 has been considered[32]. The factor analysis reduced 26 attributes into 8 factors explaing a cumulative variance of $62.3 \%$.

\subsubsection{Pre-construction management}

Pre-construction management explains the maximum variance of $14 \%$ for the attributes impacting CPP. The attributes having the factor loading more than 0.4 are inadequate project formulation, in the beginning, contractual disputes, design capability, obsolete construction equipment, and technology, and human resource and labour strike having a factor loading of $0.65,0.85,0.8,0.85$, and 0.67 respectively.

\subsubsection{Decision management}

Decision management explains a variance of $10.3 \%$ for the attributes impacting CPP. The attributes having the factor 
loading more than 0.4 are PM authority to make financial decisions, willingness to adopt change, availability to adopt changes, use of inappropriate planning tools, and claim issues having a factor loading of $0.48,0.57,0.57,0.54$, and 0.46 respectively.

\subsubsection{Stakeholder's management}

Stakeholder's management explains a variance of $9.1 \%$ for the attributes impacting CPP. The attributes having the factor loading more than 0.4 are quality, supply chain, political and economic environment, and social environment having a factor loading of $0.55,0.79,0.61$, and 0.55 respectively.

\subsubsection{Coordination and communication}

Coordination and communication explain a variance of $7.1 \%$ for the attributes impacting CPP. The attributes having the factor loading more than 0.4 are scope clarity of the project, coordination between all stakeholders developing and developing and maintaining communication, and project coordination meetings having a factor loading of 0.49 , $0.63,0.49$, and 0.4 respectively.

\subsubsection{Resource management}

Resource management explains a variance of $6.3 \%$ for the attributes impacting CPP. The attributes having the factor loading more than 0.4 are timely payment of completed works, and availability of resources having a factor loading of -0.61 , and 0.4 respectively. Timely payment having a negative factor loading because it's negatively impacting the performance of construction projects.

\subsubsection{Commercial management}

Commercial management explains a variance of $6.3 \%$ for the attributes impacting CPP. The attributes having the factor loading more than 0.4 are a regular budget update, conflict of interests among team members, and top management support to PM having a factor loading of $0.6,-0.4$, and 0.57 respectively. The conflict of interests is negatively impacting the performance of the project.

\subsubsection{Site management}

Site management explains a variance of 5\% and it acts as a factor instead of an attribute and having the factor loading of 0.62 .

\subsubsection{Rework}

Rework explains a variance of $4.3 \%$ and it also acts as a factor instead of an attribute and having a negative factor loading of -0.57 .

Table 5 factor analysis

\begin{tabular}{|c|c|c|}
\hline Attribute/variable name & Factor loading & $\begin{array}{l}\text { \%age of variance } \\
\text { explained }\end{array}$ \\
\hline Pre-construction management & & $14 \%$ \\
\hline Inadequate formulation of the project in the start & 0.65 & \\
\hline Contractual disputes & 0.85 & \\
\hline Design capability and frequent design changes & 0.80 & \\
\hline Obsolete construction equipment, and technology & 0.85 & \\
\hline labour and human resource management & 0.67 & \\
\hline Financial management & & $10.3 \%$ \\
\hline PM authority to make financial decisions & 0.48 & \\
\hline Willingness to adopt change & 0.57 & \\
\hline Availability of training and development to enhance skills & 0.57 & \\
\hline Use of inappropriate planning tools and techniques & 0.54 & \\
\hline Claim geniuses & 0.46 & \\
\hline Socio-economic management & & $9.1 \%$ \\
\hline Quality & 0.55 & \\
\hline Supply chain & 0.79 & \\
\hline political and economic environment & 0.61 & \\
\hline social environment & 0.55 & \\
\hline Coordination and communication & & $7.1 \%$ \\
\hline
\end{tabular}




\begin{tabular}{lll} 
Scope clarity of the project & 0.49 & \\
Coordination between all stakeholders & 0.63 & \\
developing and maintaining communication & 0.49 & $6.3 \%$ \\
Project coordination meetings & 0.40 & \\
Management of resources & & \\
Timely payment of completed works & -0.61 & $6 \%$ \\
Availability of resources & 0.40 & \\
Commercial management & & \\
Regular budget update & 0.60 & $5.0 \%$ \\
Conflict of interests among team members & -0.40 \\
Top management support to PM & 0.57 & \\
Site management & & \\
Site clearance/availability & 0.62 & $62.3 \%$ \\
Rework & & \\
Rework & -0.57 & \\
Total variance explained & & \\
\hline
\end{tabular}

\section{Conclusion and Recommendation}

This study analyses the impact of CP attributes over CPP using a structured questionnaire survey. The minimum RII value of top 10 attributes selected for the study is 0.67 which concluded that the attributes selected for the study having a significant impact on CPP. The cumulative variance explained by 8 factors is $62.3 \%$ i.e. by controlling and monitoring these 8 factors chances of success is $62.3 \%$. The maximum variance is explained by pre-construction management, and the least variance is explained by rework (act as a construct) are $14.3 \%$, and $4.3 \%$ respectively. Three attributes reflect negative factors loading are timely payment, conflict of interest, and rework. This study helps in defining the relationship between CP and CPP.

\section{Limitation}

This paper attempts to identify the relationship between CP and CPP and recommends the framework for the industry to grow sustainably and deliver projects successfully. This study may be conducted using a structured questionnaire survey in India and to validate the results of the study similar kind of study is required to be conducted in the other regions of the country to have more reliable findings[67].

\section{References}

[1] G. Wells and L. Evans, "The Impact of Traded Goods Prices on the New Zealand Economy*," Econ. Rec., vol. 61, no. 1, pp. 421-435, 1985.

[2] S. S. Kirmani, “The Construction Industry in Development Issues and Options,” p. 30, 1988.

[3] K. C. Iyer and K. N. Jha, "Factors affecting cost performance: Evidence from Indian construction projects," Int. J. Proj. Manag., vol. 23, no. 4, pp. 283-295, 2005.

[4] M. Arashpour, R. Wakefield, N. Blismas, and E. W. M. Lee, “Analysis of Disruptions Caused by Construction Field Rework on Productivity in Residential Projects," J. Constr. Eng. Manag., vol. 140, no. 2, p. 4013053, 2014.

[5] K. C. Iyer and K. N. Jha, "Factors affecting cost performance: Evidence from Indian construction projects," Int. J. Proj. Manag., vol. 23, no. 4, pp. 283-295, May 2005.

[6] U.S. Department of Labor, "Productivity Growth in Construction," Work. Pap. 478, vol. 142, no. October, p. 86, 2014.

[7] S. Dixit, A. K. Pandey, S. N. Mandal, and S. Bansal, “A study of enabling factors affecting construction productivity: Indian scnerio," Int. J. Civ. Eng. Technol., vol. 8, no. 6, 2017.

[8] T. Built and H. E. Review, "Evaluating Research Methodology in Construction Productivity Studies," Built Hum. Environ. Rev., vol. 3, no. 1, pp. 63-85, 2010.

[9] S. G. Allen, "Why Construction Industry Productivity Is Declining Author ( s ): Steven G . Allen Source : The Review of Economics and Statistics, Vol . 67, No. 4 (Nov ., 1985 ), pp . 661-669 Published by: The MIT Press Stable URL : http://www.jstor.org/stable/1924,” vol. 67, no. 4, pp. 661-669, 2016.

[10] L. Ruddock and S. Ruddock, "Evaluation of trends in the UK construction industry using growth and productivity accounts," Constr. 
Manag. Econ., vol. 29, no. 12, pp. 1229-1239, 2011.

[11] M. Abdel-Wahab and B. Vogl, "Trends of productivity growth in the construction industry across Europe, US and Japan," Constr. Manag. Econ., vol. 29, no. 6, pp. 635-644, 2011.

[12] B. Vogl, "Measuring Construction: Prices, Output and Productivity," Constr. Manag. Econ., vol. 33, no. 9, pp. 775-777, 2015.

[13] K. W. Chau, "Explaining Total Factor Productivity Trend in Building Construction: Empirical Evidence from Hong Kong," Int. J. Constr. Manag., vol. 9, no. 2, pp. 45-54, 2009.

[14] Y. Hung Chiang, J. Li, T. N. Y. Choi, and K. Fai Man, “Comparing China Mainland and China Hong Kong contractors' productive efficiency,” J. Facil. Manag., vol. 10, no. 3, pp. 179-197, 2012.

[15] V. A. Zeithaml, "Service quality, profitability, and the economic worth of customers: What we know and what we need to learn," $J$. Acad. Mark. Sci., vol. 28, no. 1, pp. 67-85, 2000.

[16] E. Zouher Al-Sibaie, A. Mohammed Alashwal, H. Abdul-Rahman, and U. Kalsum Zolkafli, "Determining the relationship between conflict factors and performance of international construction projects," Eng. Constr. Archit. Manag., vol. 21, no. 4, pp. 369-382, 2014.

[17] O. Ameh and E. Osegbo, "Study of relationship between time overrun and productivity on construction sites," Int. J. Constr. Supply Chain Manag., vol. 1, no. 1, pp. 56-67, 2011.

[18] L. Muhwezi, J. Acai, and G. Otim, "An assessment of the factors causing delays on building construction projects in Uganda," Constr. Eng. Manag., vol. 3, no. 1, pp. 13-23, 2014.

[19] O. I. Fagbenle, O. State, O. M. Amusan, O. State, and O. State, “ /ghzy competitive construction /Nigeria's labour intensive and 'fndustry, firms are currently applying."

[20] X. Xue, Q. Shen, Y. Wang, and J. Lu, "Measuring the Productivity of the Construction Industry in China by Using DEA-Based Malmquist Productivity Indices,” J. Constr. Eng. Manag., vol. 134, no. 1, pp. 64-71, 2008.

[21] X. Wang, Y. Chen, B. Liu, Y. Shen, and H. Sun, "A total factor productivity measure for the construction industry and analysis of its spatial difference: A case study in China," Constr. Manag. Econ., vol. 31, no. 10, pp. 1059-1071, 2013.

[22] R. Best, "Using purchasing power parity to assess construction productivity," vol. 10, pp. 1-10, 2010.

[23] P. E. J. Sugarman, “United States Patent,” vol. 2, no. 12, 2008.

[24] J. Yuventi, R. Levitt, and H. Robertson, "Organizational Barriers to Productivity and Innovation in Large-Scale, US-Based Photovoltaic System Construction Projects," J. Constr. Eng. Manag., vol. 139, no. 10, p. 5, 2013.

[25] B. Dyer, P. M. Goodrum, and K. Viele, "Effects of Omitted Variable Bias on Construction Real Output and Its Implications on Productivity Trends in the United States," J. Constr. Eng. Manag., vol. 138, no. 4, pp. 558-566, 2012.

[26] O. Moselhi and Z. Khan, "Significance ranking of parameters impacting construction labour productivity," Constr. Innov., vol. 12, no. 3, pp. 272-296, 2012.

[27] O. Moselhi and Z. Khan, "Analysis of labour productivity of formwork operations in building construction," Constr. Innov., vol. 10, no. 3, pp. 286-303, 2010.

[28] H. Rashid, "Construction Management: A Professional Approach of Factors Affecting the Labor Productivity,” no. 1, pp. 283-287, 2015.

[29] A. Panas and J.-P. Pantouvakis, "Efficiency multipliers for construction productivity: A Comparative Evaluation," Organ. Technol. Manag. Constr. an Int. J., vol. 7, no. 1, pp. 1186-1196, 2015.

[30] R. Pellegrino, N. Costantino, R. Pietroforte, and S. Sancilio, "Construction of multi-storey concrete structures in Italy: Patterns of productivity and learning curves," Constr. Manag. Econ., vol. 30, no. 2, pp. 103-115, 2012.

[31] W. Chancellor, D. Ph, W. Lu, and D. Ph, "Case Study A Regional and Provincial Productivity Analysis of the Chinese Construction Industry : 1995 to 2012," 2012.

[32] H. Doloi, "Application of AHP in improving construction productivity from a management perspective," Constr. Manag. Econ., vol. 26, no. 8, pp. 839-852, 2008.

[33] R. H. Ansah and S. Sorooshian, "Effect of lean tools to control external environment risks of construction projects," Sustain. Cities Soc., vol. 32, no. December 2016, pp. 348-356, 2017.

[34] A. M. Jarkas, C. Y. Kadri, and J. H. Younes, "A survey of factors influencing the productivity of construction operatives in the state of Qatar," Int. J. Constr. Manag., vol. 12, no. 3, pp. 1-23, 2012.

[35] "No Title," 2014.

[36] F. C. Chia, M. Skitmore, G. Runeson, and A. Bridge, "Economic development and construction productivity in Malaysia," Constr. Manag. Econ., vol. 32, no. 9, pp. 874-887, 2014.

[37] L. Zhang and W. Fan, "Improving performance of construction projects," Eng. Constr. Archit. Manag., vol. 20, no. 2, pp. 195-207, 2013.

[38] M. D. Giandrea, K. E. Cahill, A. Group, and J. F. Quinn, "Bls working papers,” no. April, 2008.

[39] M. R. Abdul Kadir, W. P. Lee, M. S. Jaafar, S. M. Sapuan, and A. A. A. Ali, "Factors affecting construction labour productivity for Malaysian residential projects," Struct. Surv., vol. 23, no. 1, pp. 42-54, 2005. 
[40] I. Mahamid, "Contractors perspective toward factors affecting labor productivity in building construction," Eng. Constr. Archit. Manag., vol. 20, no. 5, pp. 446-460, 2013.

[41] M. Chalker and M. Loosemore, "Trust and productivity in Australian construction projects: a subcontractor perspective," Eng. Constr. Archit. Manag., vol. 23, no. 2, pp. 192-210, 2016.

[42] M. Ertürk, M. Tuerdi(Maimaitiaili. Tuerdi), and A. Wujiabudula, "The Effects of Six Sigma Approach on Business Performance: A Study of White Goods (Home Appliances) Sector in Turkey,” Procedia - Soc. Behav. Sci., vol. 229, pp. 444-452, 2016.

[43] S. Mojahed and F. Aghazadeh, "Major factors influencing productivity of water and wastewater treatment plant construction: Evidence from the deep south USA,” Int. J. Proj. Manag., vol. 26, no. 2, pp. 195-202, 2008.

[44] S. Durdyev and S. Ismail, "On-site construction productivity in Malaysian infrastructure projects," Struct. Surv., vol. 34, no. 4/5, pp. 446-462, 2016.

[45] P. O. Olomolaiye, K. A. Wahab, and A. D. F. Price, "Problems influencing craftsmen's productivity in Nigeria," Build. Environ., vol. 22, no. 4, pp. 317-323, 1987.

[46] P. F. Kaming, P. O. Olomolaiye, G. D. Holt, and F. C. Harris, “Factors influencing craftsmen's productivity in Indonesia,” Int. J. Proj. Manag., vol. 15, no. 1, pp. 21-30, 1997.

[47] A. M. Jarkas and R. M. W. Horner, "Creating a baseline for labour productivity of reinforced concrete building construction in Kuwait," Constr. Manag. Econ., vol. 33, no. 8, pp. 625-639, 2015.

[48] B. D. W. Halligan, L. A. Demsetz, A. Member, J. D. Brown, and C. B. Pace, “Action-response model and,” vol. 120, no. 1, pp. 47-64, 1994.

[49] S. Ganesan, “Construction Productivity,” Habitat Int., vol. 8, no. 34, pp. 29-42, 1987.

[50] A. M. Jarkas, R. A. Al Balushi, and P. K. Raveendranath, "Determinants of construction labour productivity in Oman," Int. J. Constr. Manag., vol. 15, no. 4, pp. 332-344, 2015.

[51] K. P. Kisi, N. Mani, E. M. Rojas, and E. T. Foster, “Optimal Productivity in Labor-Intensive Construction Operations: Pilot Study,” $J$. Constr. Eng. Manag., vol. 143, no. 3, p. 4016107, 2017.

[52] S. Dixit, S. N. Mandal, A. Sawhney, and S. Singh, "Relationship between skill development and productivity in construction sector: A literature review," Int. J. Civ. Eng. Technol., vol. 8, no. 8, 2017.

[53] J. . Gosling, M. . Naim, A. . Fearne, and N. . Fowler, Defining the lean and agile characteristics of engineer-to-order construction projects, vol. 1, no. July. 2007.

[54] V. Tam, C. Tam, S. Zeng, and C. Ng, "Towards Adoption of Prefabrication in Construction Vivian W. Y. Tam 1 *, C. M. Tam 2 , S. X. Zeng 3 and William C. Y. Ng 4,” Build. Environ., pp. 1-47, 2006.

[55] M. A. Hiyassat, M. A. Hiyari, and G. J. Sweis, "Factors affecting construction labour productivity: a case study of Jordan,” Int. J. Constr. Manag., vol. 16, no. 2, pp. 138-149, 2016.

[56] S. Mahmood, S. M. Ahmed, K. Panthi, and N. Ishaque Kureshi, "Determining the cost of poor quality and its impact on productivity and profitability," Built Environ. Proj. Asset Manag., vol. 4, no. 3, pp. 296-311, 2014.

[57] M. Loosemore, "Improving construction productivity: a subcontractor's perspective," Eng. Constr. Archit. Manag., vol. 21, no. 3, pp. 245-260, 2014.

[58] A. Sao, S. Singh, S. Dixit, A. K. Pandey, and S. Singh, "Quality, productivity and customer satisfaction in service operations: An empirical study," Int. J. Mech. Eng. Technol., vol. 8, no. 10, 2017.

[59] E. Conte, "Sustainability and Built Environment: The role of Higher Education in Architecture and Building Engineering," Eur. J. Sustain. Dev., vol. 6, no. 3, pp. 1-10, 2016.

[60] R. Hughes and D. Thorpe, "A review of enabling factors in construction industry productivity in an Australian environment," Constr. Innov., vol. 14, no. 2, pp. 210-228, 2014.

[61] A. M. Jarkas, "Factors influencing labour productivity in Bahrain's construction industry," Int. J. Constr. Manag., vol. 15, no. 1, pp. 94$108,2015$.

[62] A. T. Gurmu and A. A. Aibinu, "Construction Equipment Management Practices for Improving Labor Productivity in Multistory Building Construction Projects," J. Constr. Eng. Manag., vol. 143, no. 10, p. 4017081, 2017.

[63] P. Minde, "Labour productivity in construction activity,” vol. 5, no. I, p. 2012, 2012.

[64] S. Ameh, A. Dania, I. Zubairu, and S. Bustani, "Sustainable Construction Education : Assessing the Adequacy of Built Environment Professional 'S Training," no. July, pp. 27-28, 2010.

[65] R. Parida and P. K. Ray, "Factors Influencing Construction Ergonomic Performance in India," Procedia Manuf., vol. 3, pp. 6587-6592, 2015.

[66] H. Doloi, A. Sawhney, K. C. Iyer, and S. Rentala, “Analysing factors affecting delays in Indian construction projects,” Int. J. Proj. Manag., vol. 30, no. 4, pp. 479-489, 2012.

[67] M. Abbott, "A Comparative Approach to Determining the Growth of Productivity of the New Zealand Construction Industry," Australas. J. Constr. Econ. Build., vol. 13, no. 4, pp. 65-77, 2013. 